\title{
Materials Research Society of Taiwan Will Host ICEM 1994 Under the Auspices of IUMRS
}

Hsinchu, Taiwan will be the site of the 1994 International Conference on Electronic Materials (ICEM), to be held jointly with the IUMRS-International Conference in Asia (IUMRS-ICA), December 19-22, 1994 at the Convention Center of the Industrial Technology Research Institute (ITRI).

The combined conference, organized by the Materials Research SocietyTaiwan (MRS-T) under the auspices of the International Union of Materials Research Societies (IUMRS), is being sponsored by the Republic of China (ROC) Ministry of Economic Affairs, the ROC Ministry of Education, the National Science Council, and three laboratories of the Industrial Technology Research Institute: the Electronic Research and Service Organization, the Materials Research Laboratories, and the Opto-Electronic and Systems Laboratories.
The conference program will include plenary lectures, 10 symposia with invited contributors, a joint session, and an exhibition. Special attention also will be given, on a thematic basis, to posters, with coordinated discussions of each one. Contributed papers are solicited for the following symposia:

A: Surface and Interface Structures of Electronic Materials

B: Advanced Electroceramics-

Processing and Applications

$C$ : Sensor Materials

D: Compound and Semiconducting Materials

E: ULSI Materials

F: High-Temperature Superconductors

G: Materials Technology for Displays

$\mathrm{H}$ : Materials and Technologies for

Electronic Interconnections and

Packaging

I: Recording Media

\section{J: Thin-Film Materials}

The conference will provide knowledgeable speakers with a timely forum for presenting their state-of-the-art work and progress in electronic materials and related industrial technologies. In addition, the conference committee is planning several special technical tours to promote a better understanding of Taiwan's research, development, and manufacturing in high-tech industries.

The deadline for submission of abstracts is April 15, 1994. For further information about the conference, please contact: Jonq-Min Liu, Conference Secretary Materials Research Laboratories, ITRI Conference Department, ICEM '94, Bldg. 77, 195 Chung-hsing Rd., Sec. 4 Chutung, Hsinchu 310, Taiwan, ROC; Phone 886-35-820064; fax 886-35$820247,886-35-820262$

\section{JUST PUBLISHED BY MIRS Back by Popular Demand!}

\section{Microwave Processing of Materials IL/Microwave Processing of Materials Volume 189/124}

Editors: W.B. Snyder Jr., W.H. Sutton, M.F. Iskander, D.L. Johnson/W.H. Sutton, M.H.Brooks, I.J. Chabinsky

Volumes 189 and 124 republished in a single volume for easy reference. Microwave Processing of Materials II (Volume 189) documents a symposium held at the 1990 MRS Spring Meeting in San Francisco. Microwave Processing of Materials (Volume 124), documents a symposium held at the 1988 MRS Spring Meeting in Reno, Nevada. Topics covered in Volume 189 include: international/ plenary; new applications and enhanced kinetics; design and use of materials applicators for materials processing; numerical modeling techniques; consolidation and processing of ceramics; biological effects and medical applications; industrial applications; polymer and organic materials processing; dielectric properties and measurements. Topics discussed in Volume 124: microwave processing overview; fundamentals of microwave-material interactions; dielectric property measurements; microwave processing of materials; microwave processing applications; microwave systems. Volume 189 contains 64 papers; 533 pages. Volume 124 contains 42 papers; 399 pages.

ISBN: 1-55899-214-6

$\$ 55.00$ MRS Members
\$62.00 U.S. List
Code: $189 / 124-B$ $\$ 67.00$ Foreign

\author{
Order from: \\ Materials Research Society \\ 9800 McKnight Road, Pittsburgh, PA 15237 \\ Phone (412) 367-3012; FAX (412) 367-4373
}

